ISSN : $1225-9918$

\title{
Apoptotic Effects of Resveratrol via mTOR and COX-2 Signal Pathways in MCF-7 Breast Cancer Cells
}

\author{
Sol Hwa Lee', Hye yeon Lee ${ }^{2}$, Song Yi Park', Ock Jin Park ${ }^{2}$ and Young Min Kim \\ ${ }^{1}$ Department of Biological Sciences, College of Life Science and Nano Technology, Hannam University, 461-6 Jeonmin-dong Yuseong-gu, Dagieon \\ 305-811, Korea \\ ${ }^{2}$ Department of Food and Nutrition, College of Life Science and Nano Techndogy, Hannam University, 461-6 Jeonmin-dong Yuseong-gu, \\ Dajeon 305-811, Korea
}

Received July 21, 2011 /Revised August 4, 2011 /Accepted August 22, 2011

\begin{abstract}
Resveratrol, a kind of phytochemical, is presented in grape skins. Resveratorl exerts antiproliferative, anti-cancer and pro-apoptotic activities in cancer cells. Mammalian target of rapamycin (mTOR) is a critical regulator of cellular growth and proliferation, and it is known to be a strategic target for anti-cancer therapeutic uses. mTOR is a major downstream of the PI3K/Akt pathway, which is activated in various cancer cells. It also plays an important role in the survival, proliferation and angiogenesis of cells. Cyclooxygenase-2 (COX-2) is an important protein that mediates inflammatory processes. It plays an important role in various tumors by affecting cell proliferation, mitosis, apoptosis and angiogenesis. In this study, we have investigated the effects of resveratrol on apoptosis through mTOR and COX-2 expression in MCF-7 breast cancer cells. The treatment of resveratrol with different concentrations inhibited proliferation of MCF-7. The data showed that resveratrol induced apoptotic cell death of cancer cells and decreased mTOR and COX-2 expression. These results suggest that resveratrol induces apoptosis of MCF-7 breast cancer cells by inhibiting mTOR and COX-2 expression.
\end{abstract}

Key words : Resveratrol, apoptosis, mTOR, COX-2, MCF-7 breast cancer cells

\section{서 론}

암은 비정상적인 세포의 증식이 무절제하게 일어남이 원인 이며 이러한 세포는 다양한 조직과 기관에서 발생할 수 있다. 그 중에서 유방암은 전 세계적으로 여성들에게 가장 흔히 나 타나는 암으로 산업이 발달함에 따라 발생률이 증가하며 이에 따른 사망률 또한 점점 증가하고 있는 추세이다. 유방암은 호 르몬 의존성 암으로 에스트로겐 수준에 영향을 받으며 식생활 과 출산 등 여러 가지 요인에 의해 발생한다[3]. 최근 여러 연구 에 의하면 곡류, 채소 과일 등에 포함되어있는 파이토케미컬 (phytochemical)이 세포의 여러 신호분자들을 자극하여 암세 포의 성장과 분열을 억제한다는 점에서 많은 주목을 받고 있 다[12].

레스베라트롤(resveratrol)은 피토알렉신(phytoalexin)의 일종인 파이토케미컬로 포도껍질에 존재하며 레드와인과 포 도주스에 다량 함유되어 있다[18]. 레스베라트롤은 암발생이 진행 중인 세포활동을 방해함으로써 항암작용을 하며, 심혈관 질환 예방에도 효과가 있는 것으로 알려져 있다[12]. 최근에는 레스베라트롤이 전립선암에서 apoptosis를 유발하여 암세포 의 성장을 억제하며[1], 대장암에서도 IGF-1R/Akt/Wnt 신호

*Corresponding author

Tel : +82-42-629-8753, Fax : +82-42-629-8751

E-mail : kym@hnu.kr
경로의 억제와 p53의 활성화를 통해 apoptosis를 유도하는 것 으로 보고되었다[18].

mTOR (Mammalian target of rapamycin)는 serin-threonine kinase의 일종으로 단백질 번역, 세포 성장, 증식 등의 물질대사 조절에서 중요한 역할을 하는 것으로 알려져 있다 [5]. mTOR는 세포에서 mTORC1과 mTORC2의 두 가지 복합 체로 존재하는데, 그 중 $\mathrm{mTORC1}$ 은 암세포에서 과발현되며, 단백질 번역과정에 관여하는 인자들을 활성화 시킴으로 암성 장을 촉진하는 것으로 밝혀졌다[9,15]. mTOR는 진핵세포의 개시인자인 4E-binding protein 1 (4E-BP1)과 S6 kinase 1 (S6K1)을 인산화 시킴으로 eukaryotic initiation factor $4 \mathrm{E}$ $(\mathrm{elF} 4 \mathrm{E})$ 의 활동을 자유롭게 하여 세포 증식, 성장, 혈관신생을 촉진하는 것으로 보고되었다[15].

암 치료를 위한 중요인자로 알려져 있는 Cyclooxygenase-2 (COX-2)는 유방암, 폐암, 대장암 등 여러 암종에서 apoptosis 를 저해하고 발암전구물질을 발암물질로 전환 하며, 염증반응 조절 등의 기능을 하는 것으로 알려져 있다[8]. 최근 연구를 통하여 COX-2를 저해하는 약물인 nonsteroidal antiinflammatory drugs (NSAIDs)를 이용한 실험에서 NSAIDs의 사용이 유방암 발생 비율을 감소시키며, 유방암 환자와 유방 암 세포에서 COX-2와 prostaglandin (PG) 수준이 증가하는 것으로 밝혀졌다[5]. 또한 COX-2는 폐암에서 혈관신생의 중요 인자인 vascular endothelial growth factor (VEGF)와 basic fi- 
broblast growth factor (bFGF)의 발현에 관여하여 암세포의 전이와 성장을 촉진시키는 것으로 보고되었다[8,14].

본 연구에서는 MCF-7 세포에 다양한 농도로 레스베라트롤 을 처리했을 때 MCF-7 세포의 증식이 억제되는지를 알아보 고, 암세포 증식억제 효과가 apoptosis에 의해 일어난 것인지 를 관찰하고자 하였다. 또한 MCF-7 세포에서 레스베라트롤에 의해 유도된 apoptosis가 mTOR 및 COX-2 신호경로와 어떠한 연관성이 있는지에 대해 알아보고자 하였다.

\section{재료 및 방법}

\section{재료}

레스베라트롤은 Sigma (St. Louis, MO, USA)에서 구입하여 dimethyl sulfoxide (DMSO)에 녹인 뒤 $100 \mathrm{mM}$ stock으로 만 들어 $-20^{\circ} \mathrm{C}$ 에서 보관하여 사용하였다. Hoechst 33342 , 3-(4,5-dime thylthiazol-2-yl)-2.5-diphenyltetrazolium bromide (MTT)는 Sigma에서 구입하여 멸균된 증류수에 5 $\mathrm{mg} / \mathrm{ml}$ stock으로 만들어 $4^{\circ} \mathrm{C}$ 에서 보관하여 사용하였다. Rapamycin은 (San Diego, CA)에서 구입하여 $50 \mathrm{\mu g} / \mathrm{ml}$ stock 으로 만들어 사용하였다. Celecoxib는 Sigma에서 구입하여 DMSO에 녹인 후 $100 \mathrm{mM}$ stock으로 만들어 $-20^{\circ} \mathrm{C}$ 에서 보관하 여 사용하였다.

\section{세포배양}

MCF-7 세포는 American Type Culture Collection (ATCC, Rockville, $\mathrm{MD}, \mathrm{USA}$ )에서 분양 받았으며, $10 \%$ 우태아혈청 (fetal bovine serum, FBS, Gibco BRL, Grand Island, NY, USA)과 $1 \%$ antibiotics (100 mg/l steptomycin, $100 \mathrm{U} / \mathrm{ml}$ penicillin)가 포함된 RPMI 1640 배지(WelGENE Inc, Korea) 를 사용하여 $5 \% \mathrm{CO}_{2}, 37^{\circ} \mathrm{C}$ 조건 하에서 배양하였다. 매 48 시간 마다 Trypsin-EDTA (WelGENE Inc, Korea)를 이용하여 세포 를 부유상태로 만든 다음, 세포를 $1 \times 10^{6}$ 개/ $\mathrm{ml}$ 로 분주하여 계 대하였다.

\section{MTT assay에 의한 세포생존율 측정}

세포배양용 12 well plate에 MCF-7 세포를 $1 \times 10^{5}$ 개/ml로 분주하고 24 시간 동안 안정화시킨 다음 레스베라트롤을 50 $\mu \mathrm{M}, 100 \mu \mathrm{M}, 200 \mu \mathrm{M}$ 을 각각 처리하였다. Celecoxib와 rapamycin 처리시에는 celecoxib와 rapamycin을 30 분 먼저 처리 한 후 레스베라트롤을 처리하였다. 24 시간 후 $0.5 \mathrm{mg} / \mathrm{ml}$ 의 농도로 MTT를 처리한 후 1 시간 동안 $\mathrm{CO}_{2}$ incubator에서 배양한 다음 MTT 시약이 들어있는 배지를 제거한 뒤에 DMSO를 $150 \mu \mathrm{l}$ 넣어 well에 생성된 formazan을 모두 녹인 후, 96 well plate에 100 씨씩 옮겨서 Microplate Reader (BIO-RAD Laboratories, Inc. USA)로 $595 \mathrm{~nm}$ 에서 흡광도를 측정하였다.

\section{Hoechst 33342를 이용한 chromatin 염색}

Cover glass가 놓여진 12 well plate에 MCF-7 세포를 $1 \times 10^{5}$ 개 $/ \mathrm{ml}$ 로 분주하고 24 시간 동안 안정화시킨 다음 레스베라트 롤을 $50 \mu \mathrm{M}, 100 \mu \mathrm{M}, 200 \mu \mathrm{M}$ 을 각각 처리하였다. 그 다음 hoechst 33342 시약을 $10 \mu \mathrm{M}$ 의 농도로 30분 동안 처리한 뒤 $3.5 \%$ formaldehyde로 15분간 고정시킨 후에 phosphate buffered saline (PBS)으로 두 번 세척하였다. slide glass에 50\% glycerol을 이용해 부착시키고 나서 형광현미경(Olympus Optical, Tokyo, Japan)을 이용하여 관찰하였다.

\section{Apoptosis 측정}

Apoptosis는 FITC-Annexin V apoptosis detection kit (BD Pharmingen ${ }^{\mathrm{TM}}$, San Diego, CA)를 이용해 측정하였다. MCF-7 세포를 $100 \mathrm{~mm}$ dish에 배양하여 레스베라트롤을 처리한 후 24시간이 지난 뒤 Trypsin-EDTA (WelGENE Inc. Korea)를 이용하여 세포를 부유상태로 만들어 얻은 세포를 원심분리하 여 pellet을 얻었다. 그 다음에 차가운 PBS로 washing 한 후 원심분리하여 pellet을 얻은 다음 bind buffer를 이용하여 MCF-7 세포를 $1 \times 10^{6}$ 개/ml로 만들었다. MCF-7 세포에 Annexin V-fluorescein isothiocyanate와 propidium iodide 를 넣어 15 분간 반응시킨 후 유세포 분석을 통해 측정하였다.

\section{Western bloting}

세포배양용 6 well plate에 MCF-7 세포를 $1 \times 10^{6}$ 개/ml로 분 주하여 24시간 동안 배양한 다음 레스베라트롤을 처리하였다. Celecoxib와 rapamycin 처리시에는 celecoxib와 rapamycin을 30 분 먼저 처리한 후 레스베라트롤을 처리하였다. 모든 물질 을 처리한 후 6 시간 동안 $\mathrm{CO}_{2}$ incubator에서 배양한 뒤 RIPA lysis buffer [25 mM Tris-HCl (pH 8.0), 1\% NP-40, 0.5\% sodium deoxycholate, $150 \mathrm{mM} \mathrm{NaCl}$ and $1 \mathrm{mM}$ phenylmethylsulfonyl fluoride]를 각 well에 $150 \mu$ 씩 첨가하여 단백 질을 분리한 뒤 원심분리하여 상등액만 취하였다. 추출한 단 백질은 정량 후 $8 \%$ acrylamide gel을 이용하여 전기영동을 실시한 후 nitrocellulose membrane에 transfer 하였다. 그 후 $2 \%$ bovine serum albumin (BSA)를 이용해 blocking 한 후, p-mTOR, COX-2, $\beta$-actin의 1 차 항체를 밤새 $4^{\circ} \mathrm{C}$ 에서 반응시 키고 2차 항체를 결합시킨 후 실험 결과를 측정하였다.

\section{결 과}

레스베라트롤이 MCF-7 세포의 증식 및 apoptosis에 미 치는 영향

레스베라트롤이 MCF-7 세포의 증식과 apoptosis에 미치는 영향을 알아보기 위해 레스베라트롤을 농도별로 처리하여 MTT assay를 통해 암세포의 생존율을 측정하였다. 그 결과 레스베라트롤을 $50 \mu \mathrm{M}, 100 \mu \mathrm{M}, 200 \mu \mathrm{M}$ 의 농도로 24시간 처 
리했을 때 레스베라트롤의 농도가 높아짐에 따라 MCF-7 세포 의 증식이 억제되는 것을 관찰하였다(Fig. 1A). 또한 레스베라 트롤 $100 \mu \mathrm{M}$ 처리한 후 시간이 경과함에 따라 MCF-7 세포의 증식이 더욱 억제되는 것을 확인하였다(Fig. 1B). 이러한 결과 를 통해 레스베라트롤의 농도가 증가함에 따라 MCF-7 세포의 증식억제에 더욱 효과적으로 작용하는 것을 알 수 있었다.

\section{레스베라트롤에 의한 MCF-7 세포의 apoptosis 유도 효과}

레스베라트롤을 처리했을 때 MCF-7 세포의 증식이 억제된 MTT assay 실험 결과가 apoptosis에 의해 유도된 것인지를 알아보기 위해 Hoechst 33342 염색을 통해 apoptosis에서 나 타나는 염색체 응축 현상을 관찰하였다. MTT assay와 동일한 조건으로 레스베라트롤을 $50 \mu \mathrm{M}, 100 \mu \mathrm{M}, 200 \mu \mathrm{M}$ 로 24시간 처리하고 Hoechst 33342 염색을 통해 apoptosis에서 나타나는 염색체 응축 현상을 확인한 결과, 레스베라트롤의 농도가 증 가함에 따라 농도 의존적으로 염색체 응축 현상인 apoptotic body 가 더 많이 발생된 것을 알 수 있었다(Fig. 2A). 동일한 조건으로 Annexin V-propodium iodide staining을 이용하여 apoptosis가 일어난 세포를 측정한 결과, 레스베라트롤을 처 리했을 때 apoptosis가 유도됨을 역시 확인하였고 농도가 높 아짐에 따라 농도 의존적으로 apoptosis 유도가 더욱 효과적 으로 나타난다는 것을 알 수 있었다(Fig. 2B).

레스베라트롤이 COX-2와 mTOR 신호 경로에 미치는 영향 MCF-7 세포에 레스베라트롤을 농도 별로 처리했을 때 MTOR 와 COX-2 신호 분자의 조절에 어떠한 영향을 미치는지 알아 보기 위해 Western blotting을 실시하였다. Fig. $3 \mathrm{~A}$ 에서와 같 이 레스베라트롤을 $50 \mu \mathrm{M}, 100 \mu \mathrm{M}, 200 \mu \mathrm{M}$ 으로 각각 처리했 을 때, 농도 의존적으로 mTOR와 COX-2의 발현이 감소하는 것을 관찰하였다. 또한, $\mathrm{Fig}$. $3 \mathrm{~B}$ 에서와 같이 레스베라트롤을 $100 \mu \mathrm{M}$ 처리하고 $30 \mathrm{~min}, 1 \mathrm{hr}, 3 \mathrm{hr}, 6 \mathrm{hr}$ 시간이 경과함에 따라 시간 의존적으로 mTOR와 COX-2의 발현이 감소하는 것 을 확인하였다.
Rapamycin과 celecoxib가 MCF-7 세포의 증식과 mTOR, COX-2 신호 경로에 미치는 영향

본 연구에서는 rapamycin과 celecoxib를 처리하였을 때, MCF-7 세포 증식에 어떠한 영향을 미치는지 알아보고, 또 한 $\mathrm{mTOR}$ 와 COX-2 신호 분자의 조절 관계를 밝혀보고자 하였다.

먼저 rapamycin과 celecoxib가 MCF-7 세포의 증식에 어 떠한 영향을 미치는지 알아보기 위하여 MTT assay를 통해 암세포의 생존율을 측정해 보았다. 그 결과 Fig. 4 에서와 같 이 rapamycin $50 \mathrm{ng} / \mathrm{ml}$ 과 celecoxib $50 \mu \mathrm{M}$ 을 각각 처리하였 을 때, 암세포의 증식이 약 $20 \%$ 억제되는 것을 관찰하였다. 한편 레스베라트롤을 $100 \mu \mathrm{M}$ 을 처리하고 rapamycin 50 $\mathrm{ng} / \mathrm{ml}$ 을 병합처리 했을 시에는 레스베라트롤을 $100 \mu \mathrm{M}$ 을 단독 처리했을 때의 약 $60 \%$ 의 세포생존율보다 낮은 약 $50 \%$ 의 세포생존율을 보였다. 레스베라트롤을 $100 \mu \mathrm{M}$ 을 처리하 고 celecoxib $50 \mu \mathrm{M}$ 을 병합처리 했을 때, 역시 레스베라트롤 을 $100 \mu \mathrm{M}$ 을 단독 처리했을 때 약 $60 \%$ 의 세포생존율과 비교 해 보았을 때 약 $50 \%$ 로 더 낮은 세포생존율을 보였다. 이러 한 결과는 암세포의 생존과 증식을 촉진하는 $\mathrm{mTOR}$ 와 $\mathrm{COX}$ 의 활성의 저해로 인해 MCF-7 세포 증식이 억제되었기 때문 인 것으로 보인다.

mTOR와 COX-2 신호 분자의 조절 관계를 알아보기 위하여 MTT assay (Fig. 4)와 동일한 조건으로 레스베라트롤을 처리 하여 Western blotting을 실시하여 실험 결과, Fig. 5에서와 같이 Rapamycin $50 \mathrm{ng} / \mathrm{ml}$ 을 단독으로 처리하였을 때 COX-2 의 발현이 감소하였으며 Rapamycin을 처리하고 레스베라트 롤 $100 \mu \mathrm{M}$ 을 병행처리 했을 때에는 단독으로 처리했을 때보 다 MTOR와 COX-2의 활성이 더 강하게 저해됨을 확인하였다. 한편 celecoxib $50 \mu \mathrm{M}$ 을 단독으로 처리했을 때에는 mTOR의 활성에 변화가 없었으며 celecoxib와 레스베라트롤을 병행처 리 했을 때에는 $\mathrm{mTOR}$ 의 활성이 감소하는 것을 확인 할 수 있었다.

\section{(B)} MCF-7, resveratrol $100 \mu \mathrm{M}$

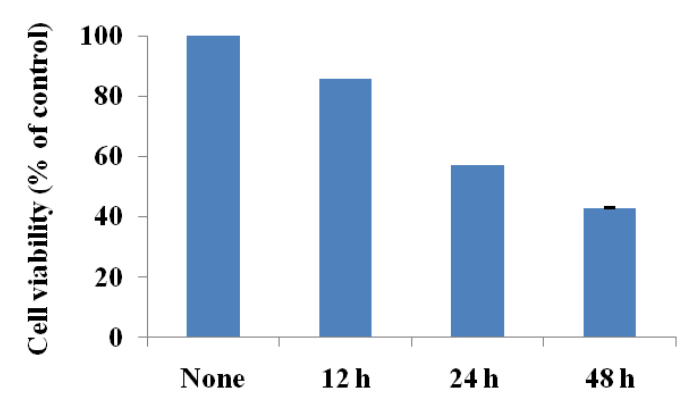

Fig. 1. Resveratrol inhibits cell proliferation in MCF-7 breast cancer cells. Cells were treated at different concentrations with resveratrol 50 200 $\mu \mathrm{M}$ (A). Cells were treated with resveratrol $100 \mu \mathrm{M}$ in $12 \sim 48 \mathrm{hr}$ (B). Cell viability was measured by MTT assay. 
(A)

MCF-7, Resveratrol ( $\mu \mathrm{M}), 24 \mathrm{~h}$

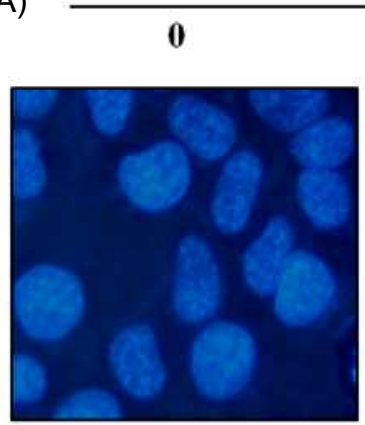

50

100

200
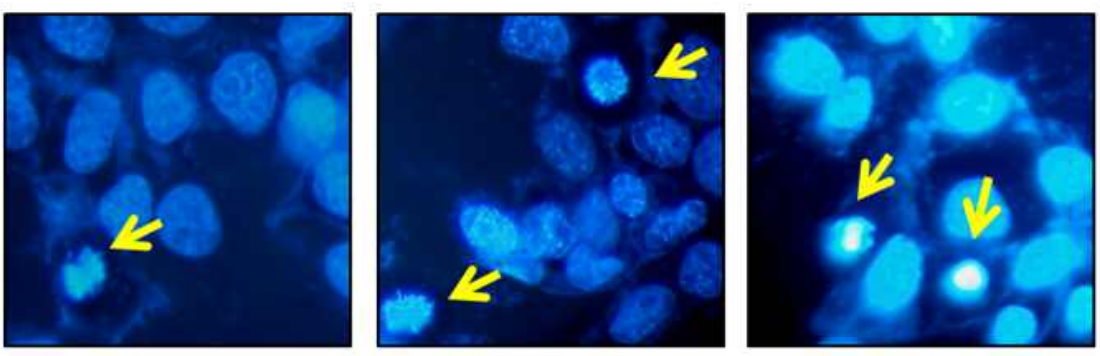

(B)

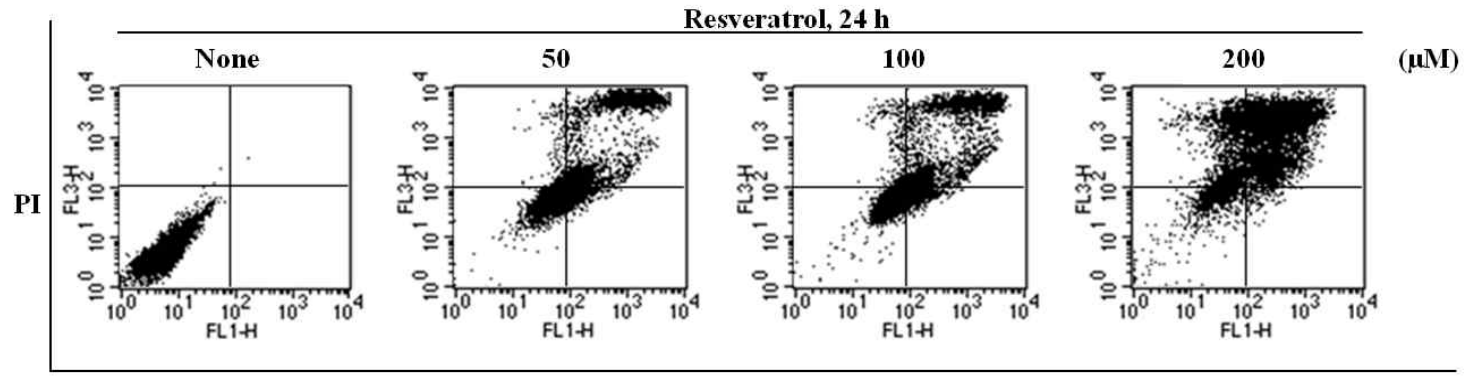

Annecxin-V

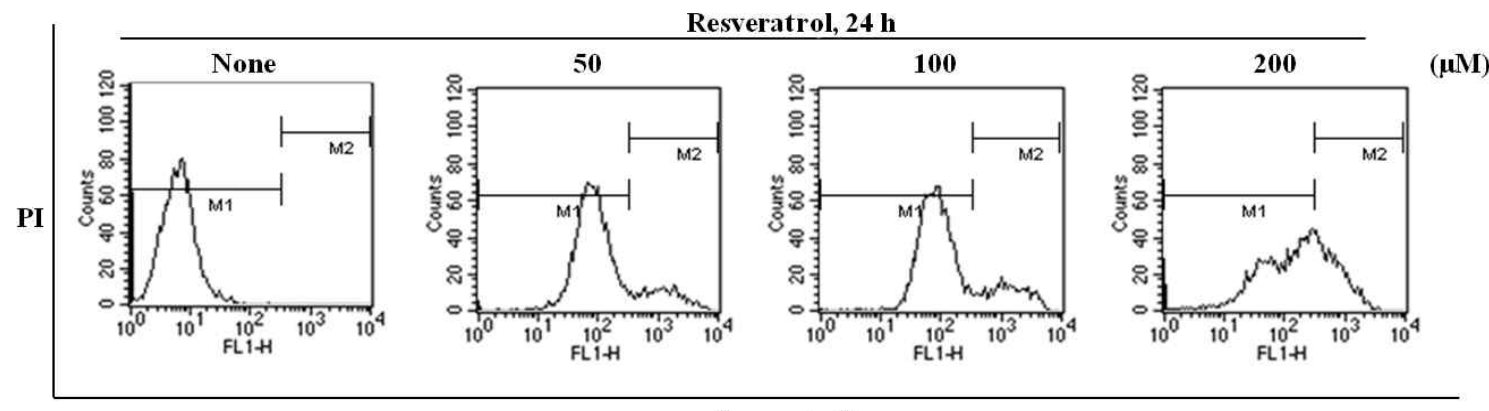

Annecxin-V

Fig. 2. Treatment of resveratrol induces apoptosis in MCF-7 breast cancer cells. Cells were treated with resveratrol $50 \sim 200 \mu \mathrm{M}$ for $24 \mathrm{hr}$. Apoptotic bodies were measured by Hochest 33342 staining. The arrows indicate cleaved nuclei in the MCF-7 breast cancer cell (A). Apoptosis was measured by Annexin V-fluorescein isothiocyanate and popidium iodide (B).

(A)

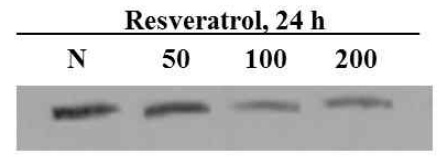

$(\mu \mathrm{M})$

p-mTOR

COX-2

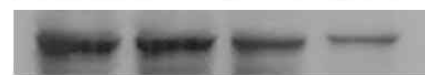

$\beta$-actin
(B)

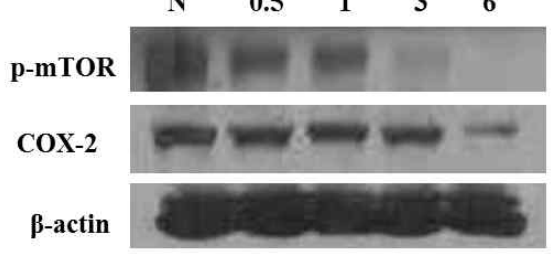

(h)

Fig. 3. Resveratrol effects on p-mTOR and COX-2 in MCF-7 breast cancer cells. Cells were treated with 50 200 $\mu \mathrm{M}$ of resveratrol (A). Cells were treated with resveratrol $100 \mu \mathrm{M}$ in 0.5-6 hr (B). Protein levels of the p-mTOR and COX-2 were determined by western blotting. 

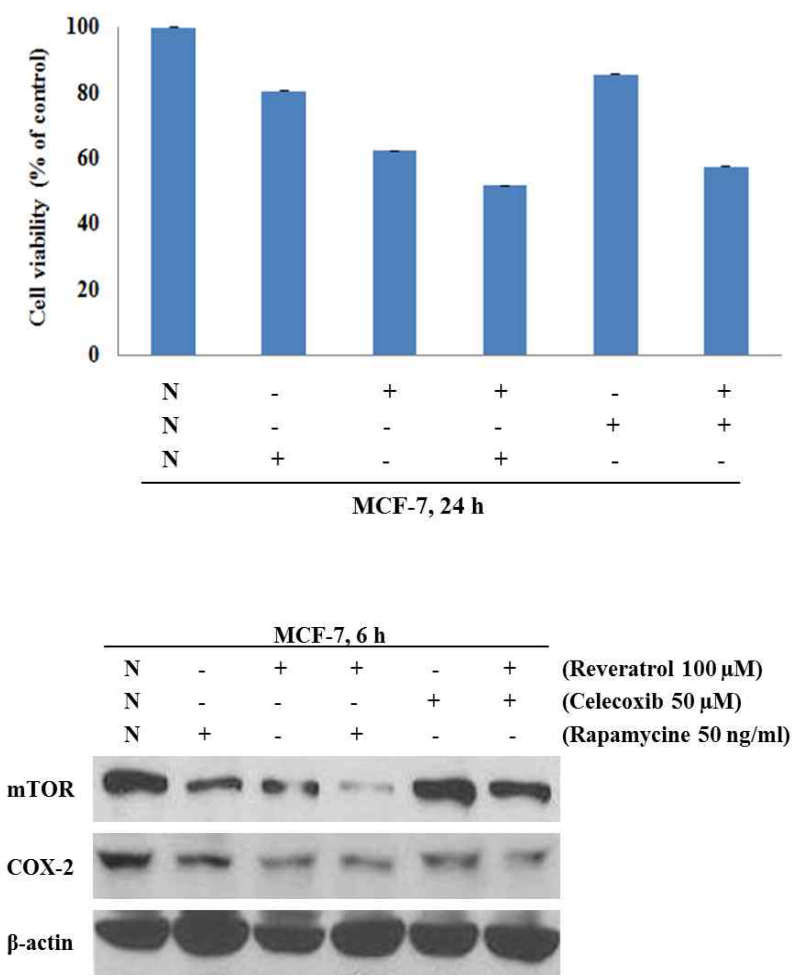

Fig. 5. Co-treatment of rapamycin and resveratrol or celecoxib and resveratrol inhibits cell proliferation and regulate p-mTOR and COX-2 in MCF-7 breast cancer cells. Cells pre-treated with rapamycin and celecoxib for $30 \mathrm{~min}$ and co-treated with resveratrol. Protein levels of them were determined by Western blotting.

\section{고 찰}

항암제를 이용한 화학적 치료는 암세포가 항암제에 약제내 성을 갖게 되어 치료 후 찾아오는 2차 발병에서 그 효과를 보기 힘들고, 암세포 뿐만 아니라 정상 세포에도 독성이 나타 나 이에 대한 여러 방안이 연구되고 있다[20]. 따라서 최근에는 파이토케미컬을 이용하여 암세포의 성장과 분열을 억제하는 연구들이 진행되고 있는 바, 녹차 성분인 Epigallocatechin3-gallate (EGCG)은 암세포에서 여러 신호경로를 통해 암세포 의 증식 억제는 물론 암 예방 효과가 있는 것으로 알려져 있으 며[7], 커큐민(curcumin)은 강황에서 추출된 폴리페놀류의 파 이토케미컬로 암세포에서 apoptosis를 유도하는 것으로 알려 져 있다[10].

$\mathrm{mTOR}$ 는 세포의 증식, 성장, 물질대사 등 여러 가지 중요한 역할을 하며[5], 다양한 암세포에서 PI3K/Akt/mTOR 신호경 로를 통해 암세포의 성장과 증식을 조절하는 것으로 알려져 있다[17]. COX-2는 염증반응을 조절하는 중요 인자로 암세포 에서 과발현되는 것으로 알려져 있다[9]. 본 연구에서는 레스 베라트롤에 의한 MCF-7 세포에서의 암세포 증식 억제 및
Fig. 4. Co-treatment of rapamycin and resveratrol or celecoxib and resveratrol inhibits cell proliferation and regulate p-mTOR and COX-2 in MCF-7 breast cancer cell. Cell treated pre-treated with rapamycin and celecoxib for 30 min and co-treated with resveratrol. Cell viability was measured by MTT assay.

apoptosis 유도 효과와, 이에 따른 mTOR 및 COX-2의 발현 양상을 알아보고자 하였다. 이를 위하여 MCF-7 세포에 레스 베라트롤을 농도별로 처리하여 암세포의 생존율을 알아본 결 과, 대조군과 비교했을 때 농도가 높아짐에 따라 암세포의 생 존율이 감소하는 것을 알 수 있었다(Fig. 1A). 동일한 방법으로 시간별 암세포의 생존율을 알아본 결과, 대조군에 비해 시간 이 경과함에 따라 암세포 생존율이 감소하는 것을 확인하였다 (Fig. 1B). 이와 같은 암세포의 생존율 감소가 apoptosis에 의해 일어나는 것인지 알아보기 위해 Hoechst 33342 염색을 통해 apoptosis에서 나타나는 염색체 응축 현상을 확인한 결과, Fig. $2 \mathrm{~A}$ 에서와 같이 레스베라트롤의 농도가 증가함에 따라 농도 의존적으로 염색체 응축 현상인 apoptotic body 가 더 많이 발생된 것을 알 수 있었고, Annexin V-propodium iodide staning을 통한 apoptosis 측정에서도 레스베라트롤의 농도가 증가함에 따라 apoptosis 유도 효과가 큰 것을 확인 하였다 (Fig. 2B). 이같은 결과는 전립선암 세포주 $\mathrm{LNCaP}$ 에 레스베라 트롤을 농도별로 처리 했을 때, APO-Direct assay를 통한 apoptosis 측정에서 레스베라트롤의 농도가 증가함에 따라 apoptosis가 유도되었고, 레스베라트롤의 처리 농도 증가는 $\mathrm{Bax}, \mathrm{Bad}, \mathrm{Bid}$ 등을 활성화 시키고 $\mathrm{Bcl}-2$ 를 저해시킴으로써 apoptosis를 촉진한다는 결과와 유사한 것으로 보인다[1]

한편 레스베라트롤을 처리했을 때 나타나는 apoptosis 유도 효과가 MTOR 및 COX-2 발현에 어떠한 영향을 미치는지 알아 보기 위해 Western blotting을 실시하였다. MCF-7 세포에 레 스베라트롤을 농도별로 $6 \mathrm{hr}$ 처리했을 때, 농도가 증가함에 따라 mTOR 및 COX-2의 발현이 감소하는 것을 확인하였고 (Fig. 3A), 레스베라트롤 $100 \mu \mathrm{M}$ 을 시간 별로 처리했을 때에도 마찬가지로 시간이 지남에 따라 $\mathrm{mTOR}$ 와 COX-2의 발현이 감 소하였다(Fig. 3B). 레스베라트롤은 HeLa, Hec-1A, KLE등의 여러 자궁암 세포주에서 EIA assay를 통한 prostaglandin E2 (PGE2) 생성실험에서 레스베라트롤의 농도가 높아짐에 따라 COX-2 대사산물인 PGE2 생성이 감소됨이 밝혀졌다[16]. 이러 한 결과는 레스베라트롤에 의한 COX-2의 발현감소와 PGE2 
생성의 유의성을 보여준다. $\mathrm{mTORC1}$ 은 암성장의 중요 인자로 알려져 있으며 암세포에서 과발현되어 있는데[10], 최근 연구 에서 mTORC1은 4E-binding protein 1 (4E-BP1)의 인산화를 조절하여 hyposia-inducible factor 1 (HIF-1)을 활성화 시켜 저산소 상태에서 암세포가 적응하고 살아남는데 필요한 유전 자를 발현시키는데 도움이 되는 것으로 알려졌다[21]. COX-2 또한 저산소상태의 암세포에서 혈관신생 유도와 관련이 있는 것으로 밝혀져 있고, $\mathrm{COX}-2$ 에 의해 생성된 산물인 PGE2가 혈관신생을 자극하며, COX-2가 과발현 되면 혈관신생 표적유 전자인 $\mathrm{VEGF}$ 의 발현이 유도되는 것으로 알려졌다[13].

Rapamycin은 mTOR의 특이적인 저해제이며, FK506 binding protein (FKB12)와 복합체를 형성하여 $\mathrm{mTORdml}$ FKBP12-Rapamycin binging (FRB) 도메인에 직접 바인딩하여 $\mathrm{mTOR}$ 의 작용을 저해한다[6]. 또한 세포분열 G1기를 정지시 켜 암세포의 증식을 억제하는 효과를 가지고 있다[2]. Celecoxib는 COX-2의 특이적인 저해제로 암세포에서 apoptosis를 일으키는 것으로 알려져 있다[11]. Rapamycin과 celecoxib가 MCF-7 세포에 어떠한 영향을 미치는지 알아보기 위 해 Rapamycin과 레스베라트롤을 각각 또는 병행처리 하고 celecoxib와 레스베라트롤을 각각 또는 병행처리하여 세포생 존율을 측정해 보았다. 그 결과 rapamycin와 celecoxib을 처리 했을 때 무처리한 것에 비하여 암세포의 생존율이 감소하였으 며 병행처리시에는 암세포의 생존율이 더욱 감소하는 것을 확인하였다(Fig. 4). 동일한 조건에서 mTOR와 COX-2 신호분 자 조절에 미치는 영향을 알아보기 위해 Western blotting을 실시한 결과, rapamycin을 단독으로 처리했을 때 COX-2의 발현이 저해되었으며 레스베라트롤과 병행처리 했을 때에 단 독으로 처리했을 때 보다 COX-2의 발현이 더 강하게 저해되 는 것을 관찰하였다. 또한 celecoxib를 단독으로 처리했을 때 에는 mTOR의 활성에 변화가 없었으며 레스베라트롤과 병행 처리 했을 때에는 mTOR의 활성이 감소하는 것으로 나타났다 (Fig. 5).

결론적으로, 본 연구를 통하여 레스베라트롤은 MCF-7 세포 의 증식을 억제하는 것으로 밝혀졌으며 이러한 증식억제가 apoptosis 의 유도에 의한 것임을 확인하였는데, 이와 같은 결과는 mTOR의 신호경로 저해를 통하여 COX-2의 발현을 감 소시킴으로써 나타나는 것으로 보인다.

\section{감사의 글}

이 논문은 2011년도 한남대학교 학술연구조성비 지원에 의 하여 연구되었음.

\section{References}

1. Aziz, M. H., M. Nihal, V. X. Fu, D. F. Jarrard, and N.
Ahmad. 2006. Resveratrol-caused apoptosis of human prostate carcinoma LNCaP cells is mediated via modulation of phosphatidylinositol 3'-kinase/Akt pathway and Bcl-2 family proteins. Mol. Cancer Ther. 5, 1335-1341.

2. Brown, E. J., M. W. Albers, T. B. Shin, K. Ichikawa, C. T. Keith, W. S. Lane, and S. L. Schreiber. 1994. A mammalian protein targeted by G1-arresting rapamycin-receptor complex. Nature 369, 756-758.

3. Chen, T. and Y. S. Wong. 2008. Selenocystine induces S-phase arrest and apoptosis in human breast adenocarcinoma MCF-7 cells by modulating ERK and Akt phosphorylation. J. Agric. Food Chem 56, 10574-10581.

4. Guertin, D. A. and D. M. Sabatini. 2005. An expanding role for mTOR in cancer. Trends Mol. Med 11, 353-361.

5. Howe, L. R., K. Subbaramaiah, A. M. Brown, and A. J. Dannenberg. 2001. Cyclooxygenase-2: a target for the prevention and treatment of breast cancer. Endocr Relat Cancer. 8, 97-114.

6. Huang, S., M. A. Bjornsti, and P. J. Houghton. 2003. Rapamycins: mechanism of action and cellular resistance. Cancer Biol. Ther. 2, 222-232.

7. Hwang, J. T., J. Ha, I. J. Park, S. K. Lee, H. W. Baik, Y. M. Kim, and O. J. Park. 2006. Apoptotic effect of EGCG in HT-29 colon cancer cells via AMPK signal pathway. Cancer Lett. 248, 115-121.

8. Kim, M. H., S. S. Seo, Y. S. Song, D. H. Kang, I. A. Park, S. B. Kang, and H. P. Lee. 2003. Expression of cyclooxygenase-1 and -2 associated with expression of VEGF in primary cervical cancer and at metastatic lymph nodes. Gynecol. Oncol. 90, 83-90.

9. Lee, Y. K., S. Y. Park, Y. M. Kim, and O. J. Park. 2009. Regulatory effect of the AMPK-COX-2 signaling pathway in curcumin-induced apoptosis in HT-29 colon cancer cells. Ann. N Y Acad Sci. 1171, 489-494.

10. Lee, Y. K., S. Y. Park, Y. M. Kim, D. C. Kim, W. S. Lee, Y. J. Surh, and O. J. Park. 2010. Suppression of mTOR via Akt-dependent and -independent mechanisms in selenium-treated colon cancer cells: involvement of AMPKalpha1. Carcinogenesis 31, 1092-1099.

11. Li, W., H. R. Jiang, X. L. Xu, J. Wang, J. Zhang, M. L. Liu, and L. Y. Zhai. 2010. Cyclin d1 expression and the inhibitory effect of celecoxib on ovarian tumor growth in vivo. Int. J. Mol. Sci. 11, 3999-4013.

12. Liu, R. H. Potential synergy of phytochemicals in cancer prevention: mechanism of action. 2004. J. Nutr. 134, 3479S3485 S.

13. Liu, X. H., A. Kirschenbaum, S. Yao, M. E. Stearns, J. F. Holland, K. Claffey, and A. C. Levine. 1999. Upregulation of vascular endothelial growth factor by cobalt chloride-simulated hypoxia is mediated by persistent induction of cyclooxygenase-2 in a metastatic human prostate cancer cell line. Clin. Exp. Metastasis 17, 687-694.

14. Marrogi, A. J., W. D. Travis, J. A. Welsh, M. A. Khan, H. Rahim, H. Tazelaar, P. Pairolero, V. Trastek, J. Jett, N. E. Caporaso, L. A. Liotta, and C. C. Harris. 2000. Nitric oxide synthase, cyclooxygenase 2 , and vascular endothelial 
growth factor in the angiogenesis of non-small cell lung carcinoma. Clin. Cancer Res. 6, 4739-3744.

15. Meric-Bernstam, F. and A. M. Gonzalez-Angulo. 2009. Targeting the mTOR signaling network for cancer therapy. J. Clin. Oncol. 27, 2278-2287.

16. Sexton, E., C. Van Themsche, K. LeBlanc, S. Parent, P. Lemoine, and E. Asselin. 2006. Resveratrol interferes with AKT activity and triggers apoptosis in human uterine cancer cells. Mol. Cancer 17:45, doi: 10.1186/1476-4598-5-45.

17. Stylianou, K., I. Petrakis, V. Mavroeidi, S. Stratakis, E. Vardaki, K. Perakis, S. Stratigis, A. Passam, E. Papadogiorgaki, K. Giannakakis, L. Nakopoulou, and E. Daphnis. 2011. The PI3K/Akt/mTOR pathway is activated in murine lupus nephritis and downregulated by rapamycin. Nephrol. Dial. Transplant 26, 498-508.

18. Vanamala, J., L. Reddivari, S. Radhakrishnan, and C. Tarver. 2010. Resveratrol suppresses IGF-1 induced human colon cancer cell proliferation and elevates apoptosis via suppression of IGF-1R/Wnt and activation of p53 signaling pathways. BMC Cancer 10, 238.

19. Wang, T. T., N. W. Schoene, Y. S. Kim, C. S. Mizuno, and A. M. Rimando. 2010. Differential effects of resveratrol and its naturally occurring methylether analogs on cell cycle and apoptosis in human androgen-responsive LNCaP cancer cells. Mol. Nutr. Food Res. 54, 335-344.

20. Yoeli-Lerner, M., G. K. Yiu, I. Rabinovitz, P. Erhardt, S. Jauliac, and A. Toker. 2005. Akt blocks breast cancer cell motility and invasion through the transcription factor NFAT. Mol. Cell 20, 539-550.

21. Zhang, J., J. Cao, Q. Weng, R. Wu, Y. Yan, H. Jing, H. Zhu, Q. He, and B. Yang. 2010. Suppression of hypoxia-inducible factor 1a (HIF-1a) by tirapazamine is dependent on eIF2a phosphorylation rather than the mTORC1/4E-BP1 pathway. PLoS One 5, 11. 13910.

\section{초록 : MCF-7 유방암 세포에서 mTOR-COX-2 신호경로를 통한 resveratrol의 apoptosis 효과}

이솔화 ${ }^{1} \cdot$ 이혜연 ${ }^{1} \cdot$ 박송이 ${ }^{1} \cdot$ 박옥진 $^{2} \cdot$ 김영민 ${ }^{1} \star$

( ${ }^{1}$ 한남대학교 생명나노과학대학 생명과학과, ${ }^{2}$ 식품영양학과)

식물에서 추출한 파이토케미컬은 암세포의 여러 신호전달 기작에 관여함으로써 apoptosis를 유도한다. 본 연 구에서는 파이토케미컬의 한 종류인 레스베라트롤을 MCF-7 세포에 처리함으로써 암세포의 증식 억제와 apoptosis 유도 효과를 알아보았고, 이러한 효과가 암세포의 성장과 증식에 관여하는 단백질인 mTOR와 COX-2의 발현 양상에 어떠한 영향을 미치는지 알아보고자 하였다. 그 결과 MCF-7 세포에 레스베라트롤을 처리했을 때 농도가 증가함에 따라 암세포의 생존률이 감소하였고, Hoechst 33342를 이용한 chromatin 염색과 Annexin V-propodium iodide staning을 통하여 암세포의 세포증식 효과가 apoptosis에 의해 유도된 것임을 알 수 있었다. MCF-7 세포에 레스베라트롤을 처리했을 때 mTOR 및 COX-2의 발현 양상을 확인하기 위해 Western blotting을 실시한 결과, 레스베라트롤의 농도가 높아짐에 따라 mTOR 및 COX-2의 발현이 감소함을 확인 하였다. 이와 같은 결과는 MCF-7 유방암 세포에서 레스베라트롤에 의한 암세포의 증식 억제 및 apoptosis 유도가 mTOR 신호경로 저해를 통한 COX-2의 발현을 감소시킴으로써 나타나는 것으로 보인다. 